\title{
FUNGSI TAMAN WISATA KOTA GIRI MENANG GERUNG KECAMATAN GERUNG KABUPATEN LOMBOK BARAT
}

\author{
${ }^{1}$ Nurin Rochayati, ${ }^{2}$ Agung Pramunarti, ${ }^{3}$ Eny Rahmawati \\ ${ }^{1,2,3}$ Dosen Program Studi Pendidikan Geografi, Universitas Muhammadiyah Mataram \\ Email: nurin.geo99@gmail.com
}

\begin{abstract}
ABSTRAK
Taman wisata kota merupakan salah satu dari industri baru, yang mampu menyediakan pertumbuhan ekonomi yang tepat dalam hal kesempatan kerja, pendapatan, taraf hidup dan dalam mengaktifkan sektor produksi lain. Taman kota dijadikan sebagai bagian dari ruang publik, sering tidak disadari oleh masyarakat kota akan peranannya dalam menyelaraskan pola kehidupan kota yang sehat, keberadaan taman wisata kota ini bukan sekedar menjadi tempat rekreasi tetapi juga tempat mencari nafkah penduduk Gerung. Masalah yang diangkat dalam penelitian ini yaitu apa saja fungsi keberadaan Taman Wisata Kota Giri Menang Gerung. Dampak positif dan negatif Keberadaaan Taman Wisata Kota Giri Menang Gerung. Tujuan penelitian ini adalah untuk mengetahui fungsi dan manfaat dan untuk menegtahui dampak positif dan negatif yang terdapat di Taman Wisata Kota Giri Menang Gerung. Metode yang digunakan dalam penelitian ini adalah metode penelitian kualitatif. Lokasi penelitian adalah di Desa Gerung. Jenis data yang di gunakan adalah data kualitatif dan sumber data menggunakan data primer dan data sekunder. Sedangkan metode penentuan informannya menggunakan informan kunci dan informan biasa, serta menggunakan puposive sampling. Informan kunci adalah Kepala Desa Gerung ,kepala Dusun Gerung Dan Tokoh Agama Gerung Giri Menang sedangkan informan biasa adalah pengunjung dan masyarakat yang tinggal di sekitar obyek taman swisata kota.Teknik pengumpulan data yang di gunakan dalam penelitian ini adalah menggunakan metode observasi, wawancara, dan dokumentasi. Dengan menggunakan tekhnik analsis data, mengikuti alur kegiatan seperti yang dijelaskan oleh Miles and Hubermen: Data reduksi (Reduksi data), Data display (Penyajian data), dan Menarik kesimpulan dan verifikasi. Bersadasarkan analisis data, disimpulkan bahwa taman wisata kota memiliki fungsi yaitu,1) sebagai tempat rekreasi, 2) tempat olah raga, 3) tempat bermain anak, 4) dari segi ekonomi, 5) budaya, lingkungan hidup, 6) dari segi pergaulan dan ilmu pengetahuan. Selain itu juga memiliki dampak positif yaitu, 1) bidang budaya, 2) bidang ekonomi dan dampak negatif nya yaitu , 1) harga barang atau jasa pelayanan menjadi naik, 2) dari segi pergaulan, 3) terjadinya pengerusakan lingkungan dan pengalihan fungsi lahan.
\end{abstract}

Kata kunci: Taman Wisata Kota

\section{PENDAHULUAN}

Pada prinsipnya pariwisata merupakan kegiatan yang mengharapkan kedatangan konsumen secara langsung di tempat wisata yang diselenggarakan. Aset yang penting untuk menarik kunjungan wisatawan adalah keaslian, kenyamanan dan keindahan alam (Sutjipta, 2001: 95). Provinsi Nusa Tenggara Barat salah satu daerah yang kaya akan objek wisata yang mempunyai daya tarik misalnya, wisata alam, wisata buatan, wisata sejarah wisata seni dan budaya. Berbagai jenis wisata tersebut yang paling terkenal di Kabupaten Lombok Barat yaitu wisata buatan, Taman Wisata Kota ini sudah melekat pada masyarakat. Taman Wisata Gerung Giri Menang merupakan taman wisata yang berada di tengah-tengah kota.

Keberadaan taman wisata kota ini bukan sekedar menjadi tempat rekreasi semata, tetapi juga tempat mencari nafkah bagi warga penduduk sekitarnya. Tidak hanya pada sore hari, namun setiap hari taman ini selalu ramai dikunjungi wisatawan padahal taman wisata koata ini baru berkembang dan masih bisa dikembangkan sesuai peraturan daerah Provinsi Nusa Tenggara Barat No 3 Tahun 2010 tentang rencana tataruang wilayah Provinsi NTB Tahun 2010.

Kegiatan pariwisata akan memperluas kesempatan tenaga kerja baik dari kegiatan pembangunan, sarana dan prasarana maupaun dari berbagai sektor usaha yang lansung maupun tidak langsung yang berkaitan dengan kepariwisataan. Pariwisata akan dapat menumbuhkan dan meningkatkan pengenalan dari cinta terhadap tanah airnya, sehingga dapat memotivasi sikap teloransi dalam pergaulan yang merupakan kekuatan dalam pembangunan bangsa, selain itu juga pariwisata mampu memperluas cakrawala pandangan pribadi terhadap nilai-nilai kehidupan.

Dari segi ekonomi, kegiatan pariwisata dapat memberikan sumbangan terhadap penerimaan daerah yang bersumber dari pajak, retribusi, parkir dan karcis atau dapat mendatangkan devisa dari para wisatawan mancanegara yang berkunjung. Adanya taman wisata juga akan menumbuhkan usaha-usaha ekonomi yang 
saling merangkai dan menunjang kegiatannya sehingga dapat meningkatkan pendapatan masyarakat.

Taman kota dijadikan sebagai bagian dari ruang publik, sering tidak disadari oleh masyarakat kota akan peranannya didalam menyelaraskan pola kehidupan kota yang sehat. Pemanfaatan ruang taman kota cenderung menyimpang dari fungsinya, adanya perubahan aktifitas didalam taman menunjukkan kekurang pahamn masyarakat kota didalam pemnfaatan keberadaan taman wisata kota terhadap keseimbangn kehidupan lingkungan kota. Makna yang sangat mendalam mengenai kota yang berwawasan lingkungan adalah selalu menghadirkan taman yang hijau mrnjadi elemen utama yang tidak dapat ditinggalkan begitu saja. Bahkan karakter masyarakat sebuah kota dapat tercermin pada prilaku masyarakat kota didalam memanfaatkan keberadaan taman wisata kota. Begitu berperannya atas keberadaan taman wisata kota terhadap pemenuhan kebutuhan masyarakat kota akan fasilitas ruang fublik, sehingga memerlukan pemikiran yang tidak bisa dilakukan dengan upaya yang kurang bijaksana.

Salah satu dari upaya, memikirkan peran taman wisata kota terhadap lingkungannya adalah dengan mengetahui tingkat pemahaman masyarakat akan bentuk visual tata hijau yang ada dalam taman tersebut melalui kelompok masyarakat yang sudah baik tingkat pemahamannya tentang taman wisata perkotaan. Dengan demikian akan dapat diketahui tingkat ketertarikan manyarakat kota tentang keberadaan taman wisata kota giri menang Gerung, Kecamatan Gerung, Kabupaten Lombok Barat merupakan salah satu taman aktif kota yang mempunyai karakter cukup baik dari konsep urban design, karena merupakan bagian dari ruang terbuka utama yang berpusat dikawasan Kantor Bupati Lombok Barat.

Dengan adanya berbagai macam aktivitas yang terjadi ditaman wisata kota dapat mengakibatkan berbagai macam persepsi masyarakat yang timbul, oleh karena itu pertumbuhan fisik kota sering menimbulkan permasalahan bagi lingkungan perkotaan maupun sosial masyarakat kota, salah satu kebutuhan adalah tersedianya ruang-ruang terbuka untuk mewadahi kebutuhan masyarakat dalam melakukan aktivitas sekaligus untuk mengendaliakan kenyamanan iklim mikro dan keserasian estetikannya.

Berdasarkan survey awal ditaman wisata kota giri menang gerung ini selain di jadikan tempat rekreasi juga dijadikan sebagai tempat mncari nafkah bagi penduduk yang bertempat tinggal di sekitar taman wisata. Semakin banyak para wisatawan yang berkunjug, maka semakin banyak pula masyarakat gerung mendapatkan rezeki meskipun ditaman wisata ini terdapat hanya beberapa fungsi dan manfaat dan juga mendatangkan dampak positif dan negatif. Rumusan masalah yang diangkat adalah (a) Apa saja fungsi Keberadaan Taman Wisata Kota Giri Menang Gerung Kecamatan Gerung Kabupaten Lombok Barat? (b) Apa saja dampak positif dan negatif keberadaan Taman
Wisata Kota Giri Menang Gerung Kecamatan Gerung Kabupaten Lombok Barat?.

II. Kajian Teori

A. Taman Wisata Kota

1. Pengertian Taman Wisata kota

Menurut Djamal (2005), taman adalah sebidang tanah terbuka dengan luasan tertentu di dalamnya ditanam pepohonan, perdu, semak dan rerumputan yang dapat dikombinasikan dengan kreasi dari bahan lainnya. Umumnya dipergunakan untuk olah raga, bersantai, bermain dan sebagainya. Pembuatan taman yang dilakukan oleh para penguasa kuno dalam bentuk penataan lahan pertanian dengan variasi pengairannya merupakan wujud pengakuan akan keindahan alam. Pohon yang rindang, bunga warna-warni, aliran air, batu-batu dan berbagai elemen lain dianggap sebagai karunia alam yang memiliki nilai estetika tinggi.

Pada umumnya taman wisata merupakan salah satu bentuk taman dalam cakupan kawasan sumber daya alam yang cukup luas dan lebih kompleks dibanding dengan taman rumah tinggal. Taman wisata merupakan sebidang lahan atau tapak yang memiliki batas tertentu yang didalamnya terdapat beberapa jenis tanaman tertentu secara homogen atau hererogen yang secara alami atau buatan yang ditata secara estetis sesuai dengan fungsi kondisi alam dengan sentuhan cita rasa keindahan sehingga dapat menimbulkan rasa kesejukan, keindahan kenyamanan bahkan dapat memberikan manfaat lain. Taman wisata pada umumnya diciptakan untuk sarana rekreasi keluarga yang didesain sealami mungkin. Taman wisata ini biasanya memiliki nilai ekonomi tersendiri sehingga taman diciptakan dengan areal yang luas dengan desain yang semenarik mungkin untuk memenuhi keinginan pengujung untuk bersantai.

\section{Jenis Pariwisata}

Jenis-jenis pariwisata ini muncul dikarenakan disetiap daerah maupun suatu negara umumnya dapat menyajikan berbagai antraksi wisata agar dapat menarik wisatawan untuk berkunjung kedaerah tersebut. Dari hal tersebut, maka terdapat beberapa jenis pariwisata, antara lain:

a. Pariwisata untuk menikmati perjalanan (pleasure tourism)

Pariwisata ini dilakukan oleh orang-orang yang meninggalkan tempat tinggalnya untuk berlibur, untuk mendapatkan ketenangan diluar kota atau sebaliknya untuk menikmati hiburan dikota besar. Jenis pariwisata ini menyangkut berbagai unsur yang sifatnya berbeda. Hal ini disebabkan karena pengertian pleasure sendirimempunyai kadar yang berbeda, sesuai 
dengan karakter, cita rasa, latar belakang kehidupan serta sifat dari masing-masing individu.

b. Pariwisata untuk rekreasi (recrationtourism)

Jenis pariwisata ini dilakukan oleh orang yang menghendaki pemanfaatan hari libur untuk beristirahat, melepaskan segala keletihan dan kelelahan, dengan mengunjungi tempat-tempat yang dianggap dapat menjamin tujuan rekreasi mereka, seperti tepi pantai atau pegunungan, dengan tujuan untuk menemukan kenikmatan yang mereka perlukan.

c. Pariwisata untuk kebudayaan (cultural tourism).

Jenis pariwisata ini ditandai dengan adanya rangkaian motivasi seperti keinginan untuk belajar dipusat riset, mempelajari adat-istiadat, mengjung monumen bersejarah, dll.

d. Pariwisata untuk olah raga (sport Tourism) Jenis pariwisata ini dibagi menjadi dua yaitu:

1) Big Sports Events, yaitu pariwisata olah raga besar seperti olimpiade, yang menarik perhatian tidak hanya untuk olahragawan sendiri, tetapi juga ribuan penonton.

2) Sporting tourism of the practitioners,yaitu pariwisata olahraga bagi mereka yang ingin berlatih dan memperaktikkan sendiri, seperti pendakian gunung, memancing, dll.

3) Pariwisata untuk urusan usaha dagang (busseness tourism)

Banyak kontraversi yang muncul terkait jenis pariwisata ini. Beberapa ahli teoti beranggapan bahwa perjalanan untuk keperluan usaha tidak dapat dianggap sebagai perjalanan wisata karenaunsut vuluntari atau sukarela tidak terlibat. Menurut para ahli, perjalanan usaha ini adalah bentuk profesional tavel atau perjalanan karena ada kaitannya dengan pekerjaan yang tidak memberikan pilihan bagi pelaku untuk menentukan daerah tujuan atau waktu perjalanan.

4) Pariwisata untuk brkonvensi (Convention Tourism)

Banyak konvensi atau konferensi nasional maupun internasional membuat banyak negara berusaha untuk menyiapkan dan mendirikan tempat-tempat konverensi yang lengkap dan menggunakan teknologi mutaklir yang menjamin efesiensi operasi koperensi. Hal ini dikarenakan mereka mulai menyadari besarnya potensi yang dihasilkan dari jenis pariwisata ini, dimana ribuan peserta yang hadir dalam konferensi tersebut terkadang tinggal untuk beberapa hari di negara penyelenggara.

Penggolongan jenis Pariwisata akan terlihat dari ciri-ciri khas yang ditonjolkan oleh tiap-tiap Pariwisata. Dalam Undang- Undang No. 9 Tahun 2001 tentang Kepariwisataan disebutkan bahwa obyek dan daya tarik wisata terdiri dari:
1) Obyek dan daya tarik wisata ciptaan Tuhan Yang Maha Esa, yang berwujud keadaan alam, serta flora dan fauna.

2) Obyek dan daya tarik wisata hasil karya manusia yang berwujud museum, peninggalan sejarah, wisata agro, wisata tirta, wisata buru, wisata petualangan alam, taman rekreasi dan tempat hiburan

\section{Ciri-ciri Perjalanan Wisata}

Perjalanan wisata adalah suatu perjalanan dengan ciri-ciri tertentu sebagai berikut :

a. Perjalanan keliling yang kembali lagi ke tempat asalnya.

b. Pelaku perjalanan hanya tinggal untuk sementara.

c. Perjalanan tersebut telah direncanakan terlebih dahulu.

d. Ada organisasi atau orang yang mengatur perjalanan tersebut.

e. Terdapat unsur-unsur produk wisata.

f. Ada tujuan yang ingin dicapain dalam perjalanan wisata tersebut.

g. Dilakukan dengan santai (M.Kasrul, 2002: 6)

\section{Tujuan Perjalanan Wisata}

Prioritas seseorang / kelompok untuk melakukan perjalanan wisata adalah mencari kesenangan atau kegembiraan, berikut adalah beberapa tujuan dari adanya pelaksanaan wisata:

a. Ingin bersantai, bersuka ria, rileks (lepas dari rutinitas).

b. Ingin mencari suasana baru atau suasana lain.

c. Memenuhi rasa ingin tahu untuk menambah wawasan.

d. Ingin berpetualang untuk mencari pengalaman baru.

e. Mencari kepuasan dari yang sudah didapatkan. (M.kasrul 2003: 6)

\section{Bentuk Wisata}

Ada berbagai macam bentuk perjalanan wisata ditinjau dari beberapa macam segi, yaitu :

1. Dari segi jumlahnya, wisata dibedakan atas :

a) Individual Tour (wisatawan perorangan), yaitu suatu perjalan yang dilakukan oleh satu orang atau sepasang suami istri.

b) Family Group Tour (wisata keluarga), yaitu suatu perjalanan wisata yang dilakukan oleh serombongan keluarga, yang masih mempunyai hubungan kekerabatan satu sama lain.

c) Group Tour (wisata rombongan), yaitu suatu perjalanan yang dilakukan bersama-sama dengan dipimpin oleh seseorang yang 
bertanggung jawab atas keselamatan dan kebutuhan seluruh anggotanya.

2. Dari segi kepengaturannya, wisata dibedakan atas

a) Pre-arranged Tour (wisata berencana), yaitu suatu perjalanan wisata yang jauh hari sebelumnya telah diatur segala sesuatunya, baik transportasi, akomodasi, maupun objekobjek yang akan dikunjungi.

b) Package Tour (wisata paket atau paket wisata), suatu produk wisata yang merupakan suatu komposisi perjalanan yang disusun dan dijual guna memberikan kemudahan dan kepraktisan dalam melakukan perjalanan.

c) Coach Tour (wisata terpimpin), yaitu suatu paket perjalanan ekskursi yang dijual oleh biro perjalanan dengan dipimpin oleh seorang pemandu wisata dan merupakan perjalanan wisata yang diselenggarakan secara rutin, dalam jangka yang telah ditetapkandan dengan rute perjalanan yang tertentu pula.

d) Special Arranged Tour (wisata khusus), yaitu suatu perjalanan wisata yang disusun secara khusus guna memenuji permintaan seorang langganan atau lebih sesuai dengan kepentingannya.

e) Optional Tour (wisata tambahan / manasuka), yaitu suatu perjalanan wisata tambahan diluar pengaturan yang telah disusun dan diperjanjikan pelaksanaannya, yang dilakukan atas permintaan pelanggan.

3. Dari segi maksud dan tujuannya, wisata dibedakan atas :

a) Holiday Tour (wisata liburan), suatu perjalanan wisata yang diselenggarakan dan diikuti oleh anggotanya guna berlibur,bersenangsenang dan menghibur diri.

b) Familiarization Tour (wisata pengenalan), yaitu suatu perjalanan anjangsana yang dimaksudkan guna mengenal lebih lanjut bidang atau daerah yang mempunyai kaitan dengan pekerjaannya.

c) Education Tour (wisata pendidikan), yaitu suatu perjalanan wisata yang dimaksudkan untuk memberikan gambaran, studi perbandingan ataupun pengetahuan mengenai bidang kerja yang dikunjunginya.

d) Scientific Tour (wisata pengetahuan), yaitu perjalanan wisata yang tujuan pokoknya adalah memperoleh pengetahuan atau penyelidikan suatu bidang ilmu pengetahuan.

e) Pilgrimage Tour (wisata keagamaan), perjalanan wisata guna melakukan ibadah keagamaan.

f) Special Mission Tour (wisata kunjungan khusus), yaitu perjalanan wisata dengan suatu maksud khusus, misalnya misi dagang, misi kesenian dan lain-lain g) Special Program Tour (wisata program khusus), yaitu suatu perjalanan wisata untuk mengisi kekosongan khusus.

h) Hunting Tour (wisata perburuan), yaitu suatu kunjungan wisata wisata yang dimaksudkan untuk menyelenggarakan pemburuan binatang yang diijinkan oleh penguasa setempat, untuk hiburan semata.

4. Dari segi penyelenggaraanya, wisata dibedakan atas :

a) Ekskursi (excursion), yaitu suatu perjalanan wisata jarak pendek yang ditempuh kurang dari 24 jam guna mengunjungi satu atau lebih objek wisata.

b) Safari Tour yaitu suatu perjalanan wisata yang diselenggarakan secara khusus dengan perlengkapan atau peralatan khusus pula.

c) Cruze Tour yaitu perjalanan wisata yang menggunakan kapal pesiar mengunjungi objek-objek wisata bahari, dan objek wisata di darat tetapi menggunakan kapal pesiar sebagai basis pemberangkatannya.

d) Youth Tour (wisata remaja), yaitu suatu kunjungan wisata yang penyelenggaraannya khusus diperuntukan bagi para remaja menurut golongan umus yang ditetapkan oleh hukum negara masing-masing.

e) Marine Tour (wisata bahari), suatu kunjungan objek wisata khususnya untuk menyaksikan kaindahan lautan.

Berdasarkan beberapa uraian tentang bentuk wisata diatas, dapat disimpulkan, bahwa motivasi yang mendorong wisatawan untuk mengadakan perjalanan wisata adalah sebagai berikut :

1) Dorongan kebutuhan untuk berlibur dan berekreasi,

2) Dorongan kebutuhan pendidikan dan penelitian,

3) Dorongan kebutuhan keagamaan,

4) Dorongan kebutuhan kesehatan,

5) Dorongan atas minat terhadap kebudayaan dan kesenian,

6) Dorongan kepentingan keamanan,

7) Dorongan kepentingan hubungan keluarga

8) Dorongan kepentiangan politik (Gamal Santoro 14-17).

\section{METODE PENELITIAN}

\section{A. Rancangan Penelitian}

Menurut Sugiyono (2013:18), metode penelitian kualitatif adalah metode penelitian yang berlandaskan pada filsafat postifisme digunakan untuk meneliti pada kndisi obyek alamiah, (sebagai lawannya adalah eksperimen) dimana peneliti adalah sebagai instrumen kunci, teknik pengumpulan data dilakukan dengan cara triangulasi data (gabungan), analisis data bersifat 
iduatif, dan hasil penelitian kualitatif lebih menekankan makna daripada generalisasi.

Dalam penelitian kualitatif, peneliti menjadi instrumen penelitian. Metode kualitatif digunakan untuk mendapatkan data yang mendalam, suatu data yang mengandung makna. Makna adalah data yang sebenarnya, data yang pasti yang merupakan suatu nilai data yang tampak, oleh karena itu penelitian kualitatif tidak menekankan pada makna. Sehingga dalam penelitian ini metode yang digunakan adalah metode penelitian kualitatif

\section{B. Lokasi Penelitian}

Penelitian ini di Kelurahan Gerung Kec. Gerung Kab. Lombok Barat. Alasan peneliti melakukan penelitian di Kelurahan Gerung Kec.Gerung Kab.Lombok Barat, karena dikelurahan tersebut terdapat taman wisata kota yang selalu ramai dikunjungi oleh banyak wisatawan Serta lokasinya pula sangat strategis untuk memudahkan peneliti untuk melekukan penelitian.
Taman Kota Giri Menang terletak di komplek Pusat pemerintahan Kabupaten Lombok Barat, Taman hijau itu dibangun di atas areal seluas kurang lebih 1,5 hektar, berbentuk persegi panjang. Diresmikan sebagai salah satu paru-paru kota oleh Kepala Daerah, Bupati Lombok Barat, bertepatan dengan tanggal cantik yakni pada tanggal 12 Desember 2012. Keberadaan taman menjadi salah satu bagian penting pada proses metamorfosa Lombok Barat, dibidang pembangunan Landmark. Berdampingan, sejurus dengan bangunan the capitol hill ala bencinga Dengan batas wilayah:

a. Sebelah barat berbatasan dengan Desa Otak Gerung

b. Sebelah timur bervatasan dengan Desa Bile Kedit

C. Sebelah utara berbatasan dengan Desa Dasan Geres

d. Sebelah selatan berbatsan dengan Desa Aik Ampat

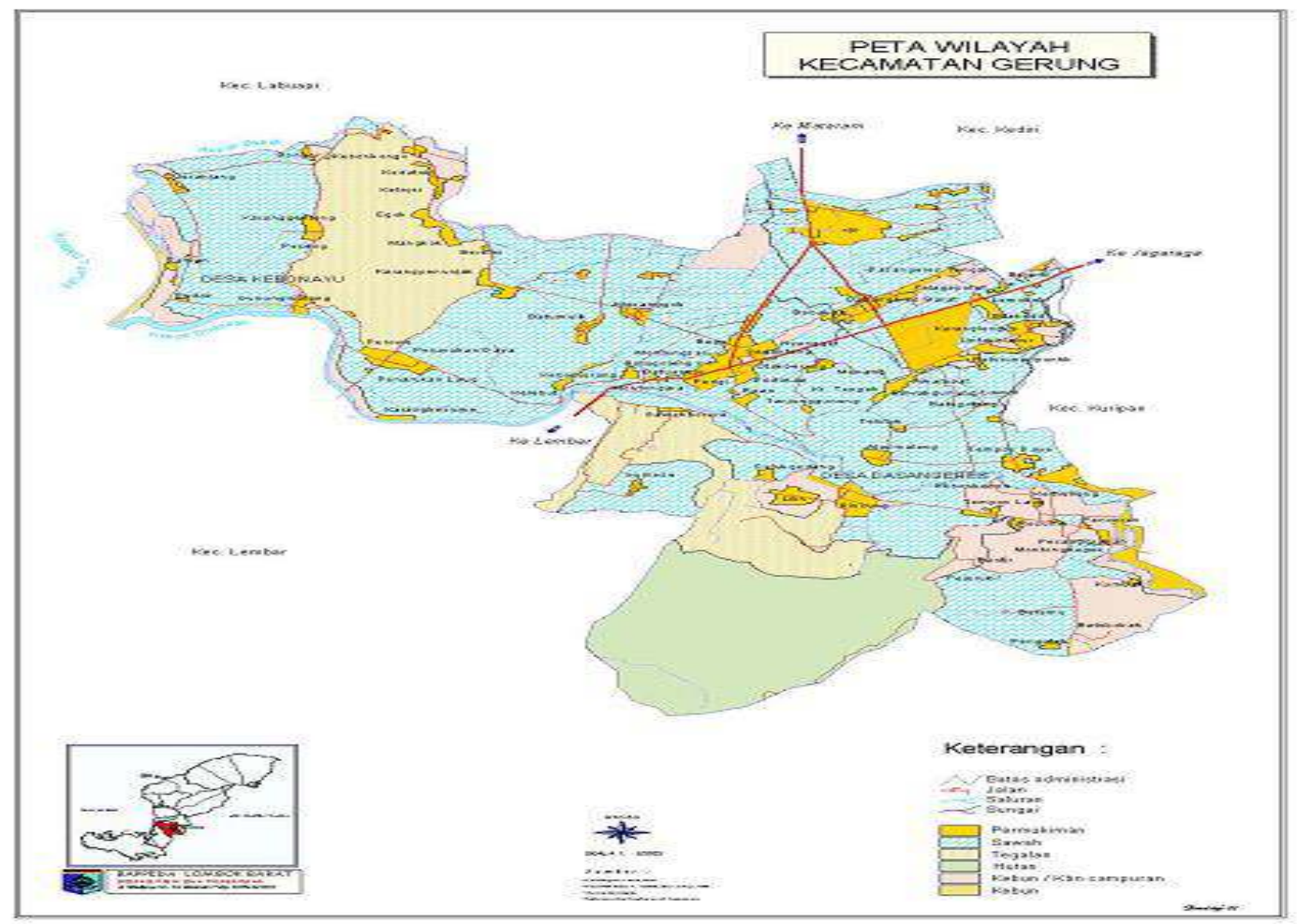

Gambar 1.

\section{Metode Penentuan Informan}

Dalam penelitian kualitatif tidak menggunakan istilah populasi tetapi oleh (Spradley dalam Sugiono, 2012) dinamakan "Social situation" atau situasi social yang terdiri atas tiga elemen yaitu: tempat (place), pelaku (actors), dan aktivitas (aktivity) yang berinteraksi secara mendalam aktivitas (activity) orang-orang (actors) tertentu. 
Cara menentukan informan adalah dengan menggunakan purposive sampling. Purposive sampling adalah tehnik pengambilan sampel sumber data dengan pertimbangan tertentu, pertimbangan tertentu ini, misalnya orang tersebut penguasa sehingga memudahkan peneliti menjelajahi obyek/situasional yang diteliti (Sugiyono, 2012:219).

Berdasarkan hal tersebut dapat disimpulkan bahwa, penentuan tehnik sampel dalam penelitian menggunakan tehnik purposive sampling. Digunakan tehnik purposive sampling ini karena informan ini dianggap lebih tahu dan lebih paham terhadap masalah yang diteliti dan dapat memberikan data yang lebih lengkap.

a) Informan kunci adalah seorang yang dapat memberikan gambarana, pemahamn tentang objek penelitian, yang menjadi informan kunci dalam penelitian ini adalah Kepala Desa dan tokoh masyarakat.

b) Informan biasa merupakansumber informasi yamg melengkapi informan kunci, yaitu masyarakat, wisatawan dan pedagang

\section{Jenis dan Sumber Data \\ 1. Jenis Data}

Jenis data dalam pelaksanaan penelitian pada hakikatnya dapat dibagi menjadi dua bagian pokok, yakni jenis data kualitatif dan kuantitatif.

Jadi data yang digunakan dalam penelitian ini adalah data kualitatif, karena penelitian ini akan menjelaskan dan mendeskripsikan informasiinformasi yang dikumpulkan dari informan.

\section{Sumber Data}

Sumber data merupakan suatu informasi yang bersumber dari dokumen tertulis, benda-benda, kejadian atau pariwisata, atau bisa juga melalui wawancara dengan subjek yang diteliti. Dalam penelitian ini sumber data yang digunakan adalah data primer. Data primer diperoleh melalui hasil wawancara tentang taman wisata kota Gerung, sedangkan data sekunder diperoleh melalui pencatatan dokumen-dokumen taman wisata kota, arsip-arsip publikasi, artikel dan gambar yang berkaitan dengan tempat wisata tersebut.

\section{E. Teknik Pengumpulan Data}

Teknik pengumpulan data merupakan langkah yang paling strategis dalam penelitian, karena tujuan utama dari penelitan adalah mendapatkan data. Tanpa mengetahui tehnik pengumpulan data, maka peneliti tidak akan mendapatkan data yang memenuhi standar data yang ditetapkan. Secara umum terdapat tiga macam tehnik pengumpulan data, yaitu observasi, wawancara, dokumentasi.

\section{Observasi}

Pengamatan atau observasi menurut (Moleong, tahun 2005: 174) adalah tehnik yang didasarkan atas pengalaman secara langsung, yang memungkinkan melihat dan mengamati sendiri secara langsung, kemudian mencatat perilaku atau kejadian dan kondisi fisik sebagaimana yang terjadi dalam keadaan sebenarnya. Dalam penelitian melekukan observasi lokasi taman wisata kota gerung giri menang, untuk mengethui kondisi dan situasi.

\section{Wawancara (Interview)}

Dalam penelitian ini menggunakan alat pengumpulan data yang berupa pedoman wawancara semi terstruktur yaitu instrumen yang berbentuk pertanyaan-pertanyaan yang diajukan secara langsung kepada informan yaitu masyarakat Gerung terhadap taman wiasata kota di Kelurahan Gerung Kec. Gerung Kab. Lombok Barat. Estebreng dalam bukunya Sugiyono (2013:73) mengemukakan ada beberapa macam wawancara yaitu : wawancara tersruktur, wawncara semi struktur, wawancara tidak terstruktur. Dalam penelitian ini, peneliti menggunakan teknik wawancara tidak terstruktur karena peneliti melakukan wawancara tidak dengan menggunakan pedoman wawancara atau tidak menyiapkan daftar pertanyaan terlebih dahulu. Tujuan dilakukan wawancara ini adalah untuk mendapatkan imformasi tentang Studi keberadaan Taman Wisata Kota Giri Menang Gerung. Kec Gerung. Kab.Lombok Barat.

\section{Dokumentasi}

Menurut Guba dan Linccoln Dalam Moleong ( 2013: 216), penggunaan metode dokumentasi diajukan untuk melengkapi dan memperkuat data dari hasil wawancara, sehingga diharapkan dapat diperoleh data yang lengkap, menyeluruh, memuaskan, dalam penelitian ini menggunakan alat pengumpulan data berupa buku-buku, majalah, serta sumber yang relevan. Dokumentasi dalam penelitian ini, misalnya data profil taman wisata kota gerung giri menang.

\section{F. Teknik Analisis Data}

Analisis data di dalam penelitian kualitatif dilakukan bersamaan dengan proses pengumpulan data. Pendekatan yang digunakan dalam penelitian ini bersifat deskriptif analisis yang merupakan proses penggambaran daerah penelitian. Pengolahan data dalam penelitian ini dilakukan dengan 3 tahap yaitu:

\section{a. Reduksi Data}

Reduksi data diartikan sebagai proses pemilihan, pemusatan perhatian pada penyederhanaan, pengabstrakan, dan transformasi data "kasar" yang muncul dari catatan-catatan tertulis di lapangan

\section{b. Sajian Data}

Sajian data adalah sekumpulan informasi tersusun yang memberi kemungkinan adanya penarikan kesimpulan dan pengambilan tindakan. 


\section{c. Kesimpulan/Verifikasi Data}

Penarikan kesimpulan hanyalah sebagian dari satu kegiatan dari konfigurasi yang utuh. Kesimpulan-kesimpulan juga diverifikasi selama penelitian berlangsung (Matthe $B$. Miles, 2002:19). Dalam penarikan kesimpulan ini didasarkan pada reduksi data dan sajian data yang merupakan jawaban atas masalah yang diangkat dalam penelitian. Secara skematis proses pensgumpulan data, reduksi data, sajian data, dan verifikasi data dapat digambarkan di bawah ini.

\section{HASIL DAN PEMBAHASAN}

A. Deskripsi Data

1. Gambaran Umum Lokasi Penelitian

Gerung adalah sebuah kecamatan di kabupaten Lombok Barat, Nusa Tenggara Barat, Indonesia. Gerung merupakan Pusat Pemerintahan Kabupaten Lombok Barat. Gerung menjadi lbukota Kabupaten Lombok Barat sejak Kota Mataram resmi menjadi Kota Madya. Karena letak Gerung yang berada di wilayah selatan Kabupaten Lombok Barat, Kecamatan-kecamatan yang berada di wilayah utara Kabupaten Lombok Barat seperti Tanjung, Bayan dan sekitarnya, meminta di bentuk Kabupaten Lombok Utara.

Tahun 2012 lalu, pemerintah kabupaten Lombok Barat menata wilayah utara kantor pemerintahannya yang berada ditengah-tengah kota menjadi icon baru kabupaten Lombok Barat yaitu dengan membangun Taman wisata kota lokasinya berada di Kelurahan Gerung Utara merupakan salah satu dari Kecamatan Gerung provinsi Nusa Tenggara Barat. Taman wisata ini ramai dikunjungi wisatawan lokal, bahkan ada juga wisatawan mancanegara yang menyempatkan diri untuk berkunjung ketempat tersebut.

\section{Kondisi Geografis}

Desa Gerung utara merupakan salah satu dari 23 Desa di Wilayah Kecamatan Gerung, yang terletak $2 \mathrm{Km}$ ke arah Utara dari Kecamatan. Desa Gerung utara mempunyai luas wilayah seluas 2366 Hektar. Iklim Desa Gerung Utara, sebagaimana desa-desa lain di wilayah Indonesia mempunyai Iklim Kemarau dan Penghujan, hal tersebut mempunyai pengaruh langsung terhadap pola tanam yang ada di Desa Gerung Utara Kecamatan Gerung Kabupaten Lombok Barat.

\section{Tingkat Pendidikan}

Distribusi penduduk di Desa Gerung kecamatan Gerung Kabupaten Lombok Barat. Kecamatan Gerung. Kabupaten Lombok Barat ini rata-rata mendapatkan pendidikan namun jika dilihat menurut agama dan kepercayaan adalah penganut agama Islam $100 \%$. Tingkat pendidikan di desa Gerung masih rendah hal itu dapat di lihat dari jumlah penduduk yang sudah mendapat pendidikan sebanyak $85 \%$ dari jumlah penduduk secara keseluruhan, yang terdiri dari jumlah penduduk yang tidak pernah sekolah sebanyak $1.19 \%$, tidak tamat SD/sederajat sebanyak $5,86 \%$, tamat SD/sederajat sebanyak $11,5 \%$, tamat SLTP/sederajat sebanyak $10,9 \%$, tamat SLTA/sederajat sebanyak $17,8 \%$, tamat D3 sebanyak $2,5 \%$ dan tamat $\mathrm{S} 1$ sebanyak $5,30 \%$. ,tamat Hal ini disebabkan karena kondisi wilayah yang jauh dari kota dan tingkat ekonominya standar.

\section{Mata Pencaharian}

Berdasarkan hasil peneliti bahwa gambaran mata pencaharian atau tingkat ekonomi penduduk masyarakat desa gerung ini mayoritas penduduknya sebagian besar petani. Desa Gerung berdasarkan fakta geografis merupakan Desa Pertanian (agraris) tetapi yang perlu diketahui bahwa sebagian besar pemilik lahan pertanian di Desa Gerung merupakan hak milik/dikuasai oleh warga yang berasal dari luar wilyah Desa Gerung sehingga penduduk yang bermata pencaharian sebagai petani sangat minim. Mata pencaharian penduduk Desa Gerung yang sangat dominan adalah buruh tani yaitu berjumlah $23 \%$ dan buruh lepas berjumlah $18.9 \%$, kemudian petani berjumlah $51,82 \%$, pedagang berjumlah $0.34 \%$ dll.

\section{B. Hasil Penelitian}

Taman Kota Gerung Giri Menang ini terdapat 4 pintu masuk Taman, saling berhubungan satu sama lain, yakni pintu utama sebelah utara dan selatan, dihubungkan oleh sebuah lorong panjang. Lorong itu lebih membentang ketimbang lorong lain, penghubung pintu masuk sebelah timur dan barat. Perpaduannya berhasil memilah taman menjadi 4 ruang yang difungsikan berbeda, yang membentuk sebuah bundaran.

1. Pada pintu masuk sebelah selatan sedikit memberi pengenalan budaya suku sasak. Pada tiap-tiap pintu masuk, tertera ukiran berbeda dengan masing-masing filosofi. Misalnya, budaya sasak, Gendang beleq.

2. Pintu masuk sebelah utara, mengandung filosofi tradisi untuk mengiringi arak-arakan penganting (nyongkolan) atau untuk penyambutan tamu agung.

3. Pada pintu masuk sebelah barat, tertera Filosofi budaya malean sampi, tradisi masyarakat agraris sebagai wujud rasa syukur atas diberikannya berkah tanah yang subur dan keberhasilan panen, tertera filosifi budaya Presean, perpaduan antara seni olah raga (wirama, wiraga dan wirasa) melambangkan kekuatan dan keberanian.

4. Dan pintu masuk sebelah timur, tertera filosifi budaya tari rudat, drama seni tari dengan gerakan bela diri (pencak silat) sebagai sarana dakwah islami yang berasal dari negeri Turki. Dari masing- 
masing Filosofi yang tertera pada keempat pintu masuk itu, pengunjung sudah dapat mempelajari sejumput budaya masyarakat sasak sebagai suguhan awal.

\section{Fungsi Keberadaan Taman Wisata Kota Giri Menang Gerung Kecamatan Gerung Kabupaten Lombok Barat}

a. Fungsi Taman Wisata Kota Giri Menang Gerung

1. Berfungsi sebagai tempat rekreasi.

Dalam setiap tempat wisata seorang wisatawan selalu mencari tempat yang nyaman dan pemandangan yang indah untuk menikmati suasana dan menghilangkan rasa jenuh yang di alami akibat dari aktivitas seharian, seperti yang di alami bagi para pegawai yang bekerja di kantor Pemerintahan Kabupaten Lombok Barat , maka dari itu setiap jam istirahat mereka bisa beristirahat di taman wisata, karena taman wisata ini berada di sekitaran kantor Pemerintahan Kabupaten Lombok Barat, dengan berekreasi maka rasa jenuh dan capek yang di alami akibat aktivitas seharian di kantor akan terasa sedikit hilang karena setelah melihat suasana pemandangan yang indah dan bisa merasakan udara yang sejuk dan segar.

Menurut Bapak Lalu Senopati Selaku kepala Desa Gerung

"Taman Wisata Kota merupakan tempat rekreasi bagi masyarakat desa maupun masyarakat kota untuk liburan atau represing". (wawancara 12 Mei 2014)

Berdasarkan pendapat informan diatas bahwa taman wisata berfungsi sebagai tempat rekreasi agar terasa sedikit hilang cara jenuh dan capek yang di alami setelah bekerja seharian, karena di taman wisata terdapat pemandangan yang indah dan terdapat udara sejuk yang di akibatkan dari banyaknya pepohonan yang menjaga kualitas lingkungan disekitaran taman wisata. Sehingga banyaknya masyarakat liburan atau represing ketaman wisata kota giri menang gerung.

2. Berfungsi sebagai tempat berolah raga.

Dengan keberadaan taman wisata giri menang gerung ini msyarakat gerung dan para wisatawan lainnya dapat melakukan olahraga. Yang hanya tersedia berupa fasilitas untuk olah raga ringan yang cukup sederhana sekedar hanya untuk menjaga kesehatan. Taman wisata kota ini memiliki beberapa fasilitas olahraga seperti: lapangan voli, lapangan basket, dan fasilitas jogging track untuk olahraga lari dan jalan kaki, jalur pijat refleksi kaki khusus untuk olahraga jalan kaki plus terapi berguna untuk penyembuhan, fasilitas jogging ini bagi para masyarakat gerung dan wisatawan lainnya. Taman kota ini juga terdapat pohon dan tanaman perdu dapat menurunkan suhu lima sampai delapan celsius, sehingga membikin suasana taman menjadi teduh, sejuk dan segar. Suasana yang demikian ini sangat sesuai untuk tempat berolah raga, karena suasana teduh, sejuk dan segar dapat menghilangkan rasa capek sehabis berolah raga.

Seperti yang dipaparkan oleh Ibu Kadijah menyatakan bahwa:

"Dengan keberadaan taman wisata kota terdapat fasilitas olahraga, sehingga saya juga bisa melakukan olah raga untuk proses penyembuhan dari penyakit rematik yang saya alami yaitu dengan berjalan di atas batu-batu kecil". (Wawancara, 12 Mei 2014)

Berdasarkan uraian di atas bahwa di dalam taman wisata kota ini terdapat beberapa fasilitas olahraga baik bagi orang dewasa maupun anak-anak sehingga banyak masyarakat melakukan olahraga agar dapat menyembuhkan penyakit yang dialaminnya, para masyarakat dan pengunjung yang melakukan olahraga sebagai proses penyembuhan dari penyakit mereka dengan harapan agar rasa sakit yang dialaminya akan segera sembuh

3. Berfungsi sebagai tempat bermain anak-anak.

Dengan keberadaan taman wisata ini selain di jadikan tempat rekreasi dan olahraga bagi orang dewasa juga terdapat beberapa tempat bermain anak-anak yang di sediakan seperti : Ayunan, Terowogan, Perosotan, Titian dan tempat bergelantungan. Dengan tersedianya fasilitas tempat bermain anakanak ini maka bisa di jadikan sebagai tempat belajar bagi anak-anak yang masih berpentidikan di tingkat TK/ PAUD. Karena pada anak-anak yang masih dalam pendidikan TK/ PAUD mereka merasa senang apabila belajar sambil bermain di tempat yang pemandangannya indah dan segar untuk mengoktimalkan proses perkembangan otak, proses perkembangan otak bisa di dapatkan salah satunya melalui bermain. Selain daripada itu para wisatawan juga merasa semakin senang mengunjungi Taman wisata kota ini. Karena selain mereka seilaku orang tua yang mendapatkan kesenagan, anak-anak mereka juga bisa kenyamanan dan kesenagan akibat tersedianya fasilitas bermain yang mereka butuhkan.

Seperti yang dikemukakan oleh Ibu Nurhayati selaku pengunjung/ Guru TK menyatakan bahwa: 
"Ditaman kota ini tersedia juga beberapa fasilitas olahraga baik bagi orang dewasa maupun anak-anak, sehingga menbuat taman ini selalu ramai dukunjungi wisatawan". (Wawancara 12 Mei 2014)

Berdasarkan hasil wawancara di atas dapat diuraikan, dengan adanya taman wisata kota ini bisa menimbulkan pola kehidupan yang sehat bagi masyarakat, wisatawan dan anak-anak kecil, karena di Taman Wisata Kota ini dilengkapi beberapa fasilitas olahraga baik bagi orang tua, remaja dan anak-anak sehingga bisa menimbulkan pola hidup yang sehat bagi masyarakat.

4. Dari Segi Ekonomi

Dengan adanya taman wisata kota bisa merubah keadaan ekonomi sebagian masyarakat Gerung karena dengan adanya taman wisata ini bisa membuka peluang kerja bagi masayarakat. Masyarakat yang dulunya jadi pengangguran sekarang sudah bisa mendapatkan pekerjaan seperti: jadi pedagang, tukang parkir, tukang sapu, dan sebagai penjaga keaman di Taman Wisata, meskipun pendapatan mereka tidak terlalu banyak akan tetapi sedikit tidak mereka bisa untuk memenuhi kebutuhan hidup seharihari.Maka dari itu keberadaan taman wisata ini sangat bermanfaat bagi masyarakat gerung karena bisa mengurangi pengangguran dkibat dari kurangnya lapangan pekerjaan

Gerung

Ibu Siti Aminah Selaku masyarakat

"Dengan adanya taman wisata ini dapat menambah kebutuhan ekonomi sebagian masyarakat Gerung, karena bisa membuka peluang kerja bagi masyarakat sehingga taman wisata ini sangat bermanfaat bagi masyarakat untuk memenuhi kebutuhan ekonomi mereka, seperti saya yang dulunya hanya berpotensi sebagai ibu rumah tangga akan tetapi sekarang saya bisa mendapatkan pekerjaan dengan adanya taman wisata ini". (wawancara 12 Mei 2014)

Berdasarkan pendapat informan di atas bahwa dengan adanya taman wisata kota Gerung Giri Menang bisa mengubah sebagian perekonomian mayarakat yang dulunya memiliki perekonomian rendah sekarang sudah lumyan meningkat sehingga kebutuhan sehari-hari mereka dapat terpenuhi.

5. Dari Segi Budaya

Selain dari segi ekonomi taman wisata juga bermanfaat dalam segi budaya. Dengan adanya taman wisata bisa di jadikan sebagai tempat pelaksanaan lomba-lomba di harihari besar seperti: lomba tari dendang beleq dan peresean yang dilaksanakan pada sore hari, sekali dalam satu tahun yaitu pada setiap Hut Lombok Barat. Lomba tari gendang beleq dilakukan dengan cara berkelompok dari berbagai kecamatan maupun desa dan lomba peresean dilakukan secara individu. Meskipun hadiah yang didapatkan bagi setiap pemenang tidak terlalu banyak atau berharga akan tetapi mereka mengikutinya dengan sungguhsunggah semata-mata untuk memeriahkan hari ulang tahun Lombok Barat. Lomba takbiran. Lomba takbiran ini di lakukan dalam setahun sekali juga yaitu pada malam hari setiap menyambut hari besar islam (Lebaran Idul Fitri). Lomba ini dilaksanakan dengan cara berkelompok dalam setiap Desa ataupun Dusun, yang di wakili atas nama masjid yang mengikuti lomba ini semua umat islam baik dikalangan orang tua, remaja dan anak-anak, hadiah yang didapatkan bagi setiap pemenang yaitu berupa fasilitas keperluan masjid. Lomba takbiran ini dilaksanakan semata-mata untuk memriahkan hari kemenangan bagi umat islam setelah menjalankan ibadah puasa sebulan penuh. Pada Tahun 2012 disaat peresmian Taman wisata kota giri menang gerung ini juga pernah dijadikan sebagai tempat pameran khas hasil produksi se Nusa Tenggara Barat.yaitu berupa pameran buku-buku, makanan khas, kesenian seperti: hasil kerajinan dan tari-tarian.

Bapak Suhirman selaku tokoh agama mengataka bahwa:

"Taman wisata kota mempunyai manfaat budaya karena taman wisata kota ini sering dijadikan sebagai tempat pelaksanaan lomba, seperti tari gendang belek, bahkan pernah juga digunakan sebagai tempat pameran khas hasil produksi se Nusa Tenggara Barat". (wawancara 12 Mei 2014)

Berdasaran pendapat infoman diatas bahwa taman wisata kota mempunyai berbagai manfaat budaya yang selalu dikembangkan oleh masyarakat gerung untuk melestarikan budayanya. Dan juga selain daripada itu bisa melakukan pertukaran budaya akibat dari adanya pameran dari hasil produksi se Nusa Tenggara Barat.

6. Dari Segi Lingkungan Hidup

Manfaat taman wisata dari segi lingkungan bisa kita rasakan secara langsung, yakni adanya udara sejuk, segar pemandangan yang indah dan alamiah yaitu akibat dari banyaknya pemohonan yang ada 
di sekitar taman wisata tersebut. Sehingaa masyarakat yang ada di wilayah Gerung tidak mengalami suhu yang terlalu panas akibat banyaknya gedung-gedung besar yang dibangun dan banyaknya polusi kendaraan yang melewati wilayah kota. Selian daripada itu juga kualitas lingkungan perkotaan yang padat aktivitas, taman wisata kota juga dapat menumbuhkan rasa sosialis yang tinggi di dalam lingkungan perkotaan yang kini mengarah pada individualis. Menumbuhkan rasa toleransi, tidak hanya terhadap sesama manusia melaikan terhadap mahkluk hidup lainnya.Dengan adanya Taman wisata kota ini merupakan sebagai cerminan kota dengan manusia (masyarakat) yang baik. Manusia (masyarakat) merupakan aspek penting dalam sebuah kota, sehingga kualitas manusia (masyarakat) akan mempengaruhi kualitas sebuah kota.

Menurut Hulaifi selaku pengunjung taman wisata kota Gerung meengatakan bahwa:

"Taman wisata kota bisa memberikan manfaat bgi lingkungan lihup karena banyaknya pohon yang ditanam disekitar taman wisata kota tersebut sehingga dapat memberikan manfaat langsung seperti udara segar dan pemandangan yang indah". (wawancara 12 Mei 2014)

Berdasarkan pendapat informan di atas bahwa taman wisata kota memberikaan manfaat langsung bagi lingkungan dan juga dapat dirasakan secara langsung oleh mayarakat gerung seperti adanya udara yang sejuk pemandangan yang indah akibat dari banyaknya pohon yang berada disekitar taman wisata tersebut.

7. Dari Segi Nilai Pergaulan dan IImu Pengetahuan.

Manfaat taman wisata dari segi nilai pergaulan adalah kita menjadi lebih banyak mempunyai teman atau kerabat dari berbagai wilayah bahkan kita juga bisa memiliki teman dari luar negeri yang mengunjungi taman wisata kota. Dan kita bisa mengetahui kebiasaan orang yang dari masing-masing wilyah tersebut sehingga kita bisa mempelajari bagaimana kebiasaan yang baik di masingmasing tersebut, dengan memiliki banyak teman kita bisa bertukar pikiran melalui berinteraksi secara langsung di taman wisata kota sehingga secara tidak langsung kita akan memiliki wawasan pengetahuan yang luas. Contoh ilmu pengetahuan mempelajari pariwisata sehingga kita tahu dimana letak dan keunggualan sebuah objek wisata dan dapat mempelajari bagaimana sebuah objek wisata tersebut bisa maju dan bisa menerapkan di daerah objek wisata yang belum berkembang dengan baik.

Seperti yang dikemukakan oleh Bapak Sami'un Selaku kepala Dusun menyatakan bahwa:

"Dengan adanya taman wisata kota ini dapat merubah pergaulan seseorang karena mempunyai banyak teman dari berbagai wilayah, dengan banyaknya teman juga dapat menambah ilmu pengetahuan atau wawasan yang luas". (wawancara, 12 Mei 2014)

Berdasarkan pendapat informan di atas bahwa taman wisata kota dapat merubah pergaulan seseorang yang dulunya hanya bergaul dengan masyarakat setempat akan tetapi dengan keberadan taman wisata kota masyarakat Gerung bisa bergaul dengan orang luar wilayah Gerung, selain itu juga bisa menambah wawasasan masyarkat Gerung menjadi lebih luas.

\section{Dampak Positif dan Negatif keberadaan Taman Wisata Kota}

\section{a. Dampak Positif Taman Wisata}

1. Bidang budaya

Keberadaan taman wisata kota dalam segi budaya merupakan suatu bagian penting dalam dunia wisata. Tanpa budaya suatu wisata akan terasa hambar dan kering. Maka dari itu peran budaya sangat penting disajikan dalam setiap perjalanan wisata. Dari budaya wisatawan akan memperoleh pengetahuan tentang budaya atau filosofi orang lain, disamping itu wisatawan bisa merasakan atau menyaksikan atraksi yang tidak terdapat di tempatnya. Gerung memiliki budaya seperti kesenian tradisional dengan ciri khas daerah adalah gamelan, kecimon, ale-ale, nyongkolan, dan tari gendang belek.

Menurut Bapak Ra'uf selaku pengunjung taman wisata kota

"Mengatakan bahwa dampak positif dari segi budayanya dengan keberadaan taman wisata kota giri menang Gerung ini kita bisa menyaksikan secara langsung kebudayaan yang ada di Gerung". (Wawancara, 12 Mei 2014)

Berdasarkan pendapat informan di atas bahwa para pengunjung yang datang ke taman wisata kota giri menang Gerung mereka dapat menyaksikan kebudayaan ynag ada di Desa Gerung yang mereka tidak ketahui, sehigga mereka daapat mempelajari 
dan menerapkannya di daerah mereka masing-masing.

2. Bidang Politik

Keberadaan objek wisata memberi manfaat untuk membina kesatuan dan persatuan bangsa. Dengan dibangunnya objek-objek wisata maka akan semakin banyak penduduk daerah mengadakan aktivitas wisata. Melalui aktivitas wisata tersebut diharapkan bagi para pengunjung memberi dampak positif, yaitu masyarakat bisa saling mengenal satu sama lainnya dengan para pengunjung atau wisatawan, agar bisa lebih dekat saling mengenal satu sama lain dan lebih akrab, serta memahami tradisi adat istiadat masyarakat masingmasing, sehingga bisa menerapkannya didaerah masing-masing, terutama bagi para pengunjung yang memiliki pengetahuan yang luas mengenai pariwisata maka masyarakat gerung bisa mempelajarinya dan menerapkannya di daerah sekitaran taman wisata, sehingga taman ini menjadi lebih terkenal sehingga banyaknya pengunjung yang mengunjungi taman wisata kota giri menang gerung ini dan dapat menghasilkan devisa yang tinggi bagi Kabupaten Lombok Barat baik dari pedagang maupun bayar parkin.

Menurut Ibu Muliani selaku pengunjung taman wisata kota Gerung mengatakan bahwa "Dengan adanya taman wisata dapat memberikan dampak positif seperti bisa menambah pendapatan daerah dengan adanya tempat wisata karena banyaknya masyarakat dan pengunjung yang datang ketempat taman wisata Gerung". (Wawancara, 12 Mei 2014)

Berdasarkan pendapat informan di atas maka Kabupaten Lombok Barat khususnya Kecamatan Gerung akan semakin meningkat pendapatan daerahnya khususnya (taman wisata Gerung) karena taman wisata ini adalah salah satu aset terpeting yang dimiliki oleh Lombok Barat, sehingga bupati Lombok Barat akan meningkatkan sarana dan prasarana ditaman wisata gerung agar semakin banyak pengunjungnya.

3. Bidang Ekonomi

Keberadaan objek wisata memberikan danpak positif di bidang ekonomi antara lain meningkatnya kesempatan kerja dan usaha, serta meningkatkan pendapatan masyarakat dan daerah. Masyarakat disekitar kawasan obyek taman wisata memiliki peluang untuk membuka usaha usaha kecil-kecilan seperti: jadi pedagang kaki lima, pedagang mailan tukang parkir, penjaga keamanan, penjaga kebersihan, tukang sapu. Dalam hal ini masyarakat berharap bahwa pemerintah bisa menyiapkan tempat untuk berjualan disekitar objek taman wisata. Karena selain bisa menambah penghasilan masyarakat juga bisa mengurangi angka pengangguran.

Seperti yang dikemukakan oleh Bapak Sami'un Selaku kepala Dusun menyatakan bahwa:

"Dengan adanya taman wisata kota Gerung ini dapat meningkatkan pendapatan masyarakat. Pengeluaran atau pembelanjaan para pengunjung akan meningkatkan pendapatan dan keuntungan bagi masyarakat setempat dan daerah". (wawancara 12 Mei 2014)

Berdasarkan pendapat informan diatas bahwa keberadaan taman wisata kota Gerung dapat menambah kebutuhan ekonomi masyarakat dengan berbelanja bahkan dapat menambah pendapatan daerah karena banyaknya pengeluarn pengunjung dengan membayar parkir di taman wisata tersebut.

\section{b. Dampak Negatif Taman Wisata}

Dampak-dampak yang tidak dinginkan karena berkembangnya kegiatan kepariwisataan si suatu daerah tujuan wisata (DTW).

1. Harga-harga barang atau jasa pelayanan menjadi naik.

Dengan banyaknya pengunjung yang datang kesuatu kawasan/daerah. Wisatawan selalu dikira membawa uang banyak maka dari itu merupakan kesempatan bagi para pedangang untuk menaikkan harga barang melonjak naik dari harga pasar seperti yang biasanya harga Air mineral yang ukuran tanggung Rp 1500 akan tetapi di kawan daerah wisata bisa melonjak dengan harga $R p$ 3000. Dan bayaran parkir ditempat lain yang semulanya hanya Rp1000 akan tetapi ditempat wisata melonjak naik menjadi $R p$ 2000. Mahalnya harga barang bukan hanya bagi para pengunjung saja yang mengalami akan tetapi masyarakan asli yang tinggal disekitaran taman wisata kota juga ikut mengalaminya, maka dari itu masayarakat sedikit mengeluh karena penghasilan mereka tidak seimbang dengan harga barang yang mereka butuhkan sehingga mereka jadi meresakan kesulitan untuk mendapatkannya.

Menurut Yanti selaku masyarakat taman wisata kota Gerung mengatakan bahwa:

"Sebelum adanya taman wisata harga barang masih optimal seperti harga pasar akan tetapi dengan keberadaan taman ini harga barang yang semulanya rendah menjadi naik". (wawancara 12 Mei 2014) 
Berdasarkan pendapat informan di atas dengan keberadaan taman wisata memberikan danpak negatif bagi masyarakat yang berpendapatan rendah akibat dari melonjakknya harga barang yang bertambah naik sehingga masyarakat merasa sulit untuk mendapatkan barang yang dibutuhkan.

2. Dalam segi pergaulan

Penduduk setempat khususnya dikalangan remaja suka mengikuti pola hidup para wisatawan seperti meniru cara berpakaian yang dulunya cara berpakain masyarakat gerung hanya biasa-biasa saja akan tetapi dengan melihat cara berpakaian para pengunjung dari daerah lain yang kelihatannya gaul dengan menggunakan rok mini maka sedikit demi sedikit masyarakat setempat akan menirunya , cara makan, serta cara hidup lainnya yang tidak sesuai dengan budaya dan kepribadian setempat.

Menurut Inak Juni selaku masyarakat Gerung menyatakan bahwa:

"Dengan adanya taman wisata kota Gerung dapat memberikan danpak negatif bagi kalangan remaja yang suka meniru wisatawan asing yang datang mengunjungi taman wisata baik cara berpakain, bergaul dan gaya hidup sehingga tidak sesuai dengan budaya dan kepribadian setempat". (wawancara 12Mei 2014)

Berdasarkan pendapat informan di atas bahwa banyak dikalangan remaja terjadi perubahan seperti baik cara berpakain, bergaul dan gaya hidup sehingga tidak sesuai dengan budaya dan kepribadian setempat, sehingga menyebabkan sedikit perubahan kepribadian dan budaya yang ada di Desa Gerung.

3. Terjadinya pengrusakan lingkungan dan pengalihan fungsi lahan. Akibat dari keberadaannya taman wisata ini mengakibatkannya terjadinya kerusakan lingkungan dari banyaknya sampah yang di buang di sembarang tempat dan banyaknya gedung-gedung besar yang dibangun. Dengan pembangunan sarana-sarana tersebut maka secara otomatis sistem penyaluran atau distribusi air terhalangi oleh beton-beton yang melintang dengan kokoh di wilayah tersebut yang mengakibatkan air tidak bisa mengalir dengan baik ke seluruh areal persawahan polusi udara semakin meningkat akibat dari banyaknya kendaraan yang melewati kawasan perkotaan. Selain terjadi pengerusakan lingkungan juga terjadi pengalihan fungsi pada lahan pertanian yang dijadikan sebagai tempat pengembangan fasilitas dan sarana pariwisata. Para petani merasa sangat rugi, karena lahan irigasi yang mereka miliki sudah tidak bisa di tanami lagi untuk bertani lagi akibat dari pembangunan fasilitas taman wisata, meskipun lahan yang mereka miliki tidak diambil secara percuma oleh pemerintah akan tetapi bibayar dengan harga lumayan rendah, maka dari itu masyarakat Gerung banyak yang mengeluh karena mereka merasakan kehilanga pekerjaan tetap mereka sebagi petani, karena sebagian besar masyarakat gerung mayoritas pekerja menjadi petani

Bapak Lalu Senopati Selaku kepala Desa menyatakan bahwa:

"Dengan dibangunnya taman wisata sebagian masyarakat mengeluh karena wilayah perkotaan menjadi semakin sempit sehingga mereka merasa wilayahnya mudah terkena banjir pada musim huian akibat dari semakin diperluas pembangunan taman wisata". (wawancara 12 Mei 2014)

Berdasarkan pendapat informan di atas taman wisata ini bisa menimbulkan kerusakan lingkungan dan pengalihan fungsi lahan terutama pada lahan pertanian yang dijadikan sebagai tempat pengembangan fasilitas dan sarana pariwisata dan dengan semakin pesatnya bangunan.

\section{Pembahasan}

Taman Wisata Kota bukan sekedar menjadi tempat rekreasi semata, tetapi juga tempat mencari nafkah bagi warga penduduk sekitarnya. Tidak hanya pada sore hari, namun setiap hari taman ini selalu ramai dikunjungi wisatawan, Taman wisata ini memiliki fungsi sebagai tempat rekreasi, karena banyaknya masyarakat liburan atau represing, tempat berolah raga bagi msyarakat gerung, dan para wisatawan lainnya, tempat bermain anak-anak, beberapa fasilitas yang di sediakan seperti: Ayunan, Terowogan, Perosotan, dan tempat bergelantungan. Semakin banyak jumlah pengunjung sangat di pengaruhi oleh upaya yang di lakukan oleh pihak pengelola terhadap obyek taman wisata tersebut memiliki manfaat selain itu jug taman wisata kota giri menang ini fungsi dan manfaat juga memiliki dampak positif dan dan dampak negatif. Untuk mengantisifasi akan terjadinya dampak negatif pada masa yang akan datang dan belum bisa diatasi. Untuk itu perlu adanya peran pemerintah untuk mengatasi dampak negatif agar Obyek Taman Wisata Giri Menang ini bisa berjalan secara maksima dan selalu dikunjungi banyak wisatawan. Jadi bila melihat dari analisis data maka Obyek Taman Wisata Kota Giri Menang ini memang pantas untuk dikembangkan karena 
keberadaannya lumayan bagus an bermanfaat bagi masyarakat Gerung

\section{PENUTUP}

A. Kesimpulan

Berdasarkan uraian pada bab sebelumnya dapat disimpulan yaitu sebagai brikut:

a. fungsi dan manfaat keberadaan taman wisata kota giri menang, Fungsi antara lain (1) Fungsi, antara lain: a) sebagai tempat rekreasi, b) sebagai tempat berolah raga, c) sebagai tempat bermain anak-anak (2) Manfaat, antara lain: Manfaat Taman Wisata dari Segi Budaya, c) Dari Segi Lingkungan Hidup dari Segi Nilai Pergaulan dan Ilmu Pengetahuan.

b. dampak positif dan negatif keberadaan taman wisata kota giri menang, (1) Dampak Positif, yaitu antara lain: a ) Bidang Budaya, b) Bidang Politik, c) Bidang Ekonomi. (2) Dampak Negatif , yaitu antara lain: a) Harga-harga barang atau jasa pelayanan menjadi naik, b) Terjadinya pengrusakan lingkungan dan pengalihan fungsi lahan, c) dalam segi lingkungan hidup.

\section{B. Saran}

a. Diharapkan kepada pemerintah untuk lebih memperhatikan tentang keberadaan taman wisata kota, serta bisa memberikan arahan yang baik kepada para semua masyarakat Gerung untuk bisa menjaga kebersihan dan keamanan taman wisata kota.

b. Diharapka kepada semua masyarakat Gerung yang berada disekitar wilayah taman wisata, untuk bisa menjaga kelestarian taman wisata kota agar bersih sehingga dapat dimanfaatkan serta dikelola oleh masyrakat gerung maupun pemerintah.

\section{DAFTAR PUSTAKA}

Arikonto, Suharsimin. 2009. Prosedur Penelitian Suatu Pendekatan Praktek. PT. Rineke Cipta. Jakarta.

Djasmin (2006). Kebijakan perusahaan untuk meningkatkan kinerja penjualan dengan meraih peluang.Diakses pada tanggal 19 januari 2014 dari http://albina.wordepes.com.

Fandeli, Chafid. 2002. Perencanaan Kepariwisataan Alam. Yogyakarta : Fakultas Kehutanan UGM dan PT. Perhutani (Persero).

Fandeli,2001. Jurnal Nasional Pariwisata. Balai Pustaka :Bandung.

Githa,2002." Kajian Prospek Dan Arahan Pengembangan Atraksi Wisata Kepulauan Karimunjaya Dalam Perspektif Konservasi Tahum ajaran 2001/2002". Diakses tanggal 18 Januari $2014 \quad$ dari http://eprints.undip.ac.id/4683/1/gitaalfa97.
Ismayanti ,2005. Pengantar Pariwisata,Grasindo;Jakarta Krugman (2007). Prospek Pengembangan Usaha. Jakarta. PustakaUtama, Jakarta

Kusmayadi dan Endar Sugiarto. 2000. Metodologi Penelitian Dalam Bidang Kepariwisataan. Jakarta : PT. Gramedia Pustaka Utama

Moleong, Lexy J, 2002. Metode Penelitian Kualitatif. PT. Remaja Rosdakarya. Bandung.

Moleong, J .Lexy,2005.Penelitian Kualitatif cetakan ke$X X I$,Tarsito:Bandung

Muhadjir,2005. Penelitian Kualitatif, Raike Sersaein:Yogyakarta

Nazir,2003.Metode Penelitian Cet 10, Ghalia Indonesia:jakartaan Dalam Bidang Kepariwisataan. Jakarta : PT. Gramedia Pustaka Utama

Pabundu Tika Moh,2005.Metode penelitian Geografi,PT Bumi Aksara:Jakarta

Rohman.(2011).Analisis SWOT tehnik Membedah Kasus Dalam Penelitian.PustakaUatama. Jakarta Pustaka.

Rumanthy, 2011. "Penilaian Ekonomi dan Prospek Pengembangan Wisata Taman Wisata Alam Gunung Pancar Tahun Ajaran 2010/2011". Diakses tanggal 18 januari 2013 dari http://repository.ipb.ac.id/handle/123456789/531 27

Sugiyono.2009.Metode Penelitian Pendekatan Kuantitatif, Kualitatif dan $R \& D$. Bandung: Alfa Beta

Suwantoro,Gamal SH. 2004.Dasar - Dasar Pariwisata, Andi : Yogyakarta

Umar, Husein (2007).Strategi Management In Action, GramediaPustakaUtama, Jakarta Selatan.

Wardiyanta,Hum Drs,2006.Metode Penelitian Geografi,Andi:Yogyakarta

Yoeti, Oka A. 2008. Ekonomi Pariwisata. kompas:jakarta

Yoeti, Oka A. (ed). 2000. Ekowisata : Pariwisata Berwawasan Lingkungan Hidup. Jakarta : PT. Pertja.

Yoety, Oka A. 2008. Perencanaan dan pengembangan pariwisata. Jakarta: PT. PradnyaParamita. 